\title{
Political Commitment of Local Government in Handling Stunting During the Covid-19 Pandemic: A Case Study of Enrekang District
}

\author{
Amran Razak $^{1}$, Sri Harpina ${ }^{2}$, Ratno Adrianto ${ }^{3}$ \\ ${ }^{1}$ Proffesor of Department of Administration and Health Policy, Hasanuddin University, Makassar 90245, \\ Indonesia, ${ }^{2}$ Staff of Enrekang District Health Office, Enrekang 91731, Indonesia, ${ }^{3}$ Lecturer Department of \\ Administration and Health Policy, Mulawarman University, Samarinda 75123, Indonesia
}

\begin{abstract}
Purpose: This study aims to determine the political commitment of the Enrekang District Government in overcoming the problem of stunting during the COVID-19 period.

Method: This study uses a qualitative research method with a type of case study research. This research was conducted in Enrekang District in May - July 2020. The informants in this study were 13 people who were selected by purposive sampling technique. Data collection was carried out by in-depth interviews, document review, and observation.

Results: The results of this study indicate that the COVID-19 pandemic has an impact on the political commitment of the Enrekang local government in handling stunting. The enactment of Large Scale Social Restriction (LSSR) and refocusing on the budget caused several programs to experience budget cuts. On the other hand, the provision of latrines for sanitation and hygiene absorbs the largest amount of funds.
\end{abstract}

Conclusions: The COVID-19 pandemic has an impact on the political commitment to handling stunting due to the enactment of Large Scale Social Restriction (LSSR) and budget refocusing.

Keywords: Political commitment, stunting, COVID-19, enrekang district.

\section{Introduction}

The problem of stunting is no less important than Covid-19. Stunting is when a child has a low height for their age, usually due to malnutrition, repeated infections, and/or poor social stimulation. The World Health Organization categorizes children who are stunted as those whose height is lower than average for their age, and at least two standard deviations below the

\section{Correspondent Author:}

\section{Amran Razak}

Proffesor of Department of Administration and Health

Policy, Hasanuddin University, Makassar 90245, Indonesia

e-mail: profamranrazak@gmail.com
WHO's Child Growth Standards Median. ${ }^{1}$ In addition to affecting the golden age of growth, the impact of stunting is expected to continue into adulthood. Currently, globally there are still 149 million children under the age of 5 who suffer from stunting. ${ }^{2}$ In Indonesia, more than 2 million children suffer from malnutrition and more than 7 million children in under 5 years of age are stunted. ${ }^{3}$ This condition requires political commitment from the central and local governments to show seriousness in food and nutrition interventions in their policy agendas. Lack of political commitment has been identified as the main reason for the low priority received by food and nutrition interventions. ${ }^{4}$

As the COVID-19 coronavirus pandemic begins to spread across the world, many countries including Indonesia have restricted movement as a way to slow the spread of the virus and give their health systems 
more time to prepare for the influx of patients. Indonesia chooses Large-Scale Social Restrictions (LSSR) to prevent transmission of COVID-19.5 However, countermeasures for COVID-19 such as self-isolation, and social distancing can lead to poor management of key risk factors such as unhealthy diet and physical activity $^{6}$, and limited access to preventive care in primary care settings.

Also, economic instability, limited travel, and access to health care services delay vaccination schedules, and the closure of educational facilities further exacerbates the poor health conditions for children, especially in low and middle income countries. ${ }^{7}$ The main sectors that are at risk of collapse or reduced efficiency after COVID-19 include food systems, income and social protection, services health care for women and children, as well as services and access to clean water and sanitation. ${ }^{8}$ Moreover, the refocusing of the budget, including programs to reduce stunting, led to a reduction in the budget for various stunting management activities in stunting-prone areas. This could have an impact on the performance of officers and cadres in dealing with stunting.

This study uses qualitative research on political commitment in handling stunting during the COVID-19 epidemic.

This study aims to determine the political commitment of the Enrekang District Government in overcoming the problem of stunting during the COVID-19 period.

Study design: A qualitative methodology was used to explore the political commitment of local governments in handling stunting before and during the Covid-19 pandemic. The design is flexible and approves of the exploration and understanding of meanings that some individuals or groups of people perceive as stemming from social or humanitarian problems. ${ }^{9}$

Instrument Development: The development of an instrument based on the main literature review on political commitment ${ }^{10-12}$ and a national strategy for reducing stunting in Indonesia (NTAPR) ${ }^{13}$, then developed a semi-structured interview guide. $^{14}$ This guide focuses on the components of political commitment to policies and programs, the size of the budget, and operational/implementation commitments for stunting in Enrekang District. These guidelines were subjected to validation and reliability assessments before data collection. Cumulative validation is used as a cross-reference method whereby researchers use accessible literature to match findings. Based on the nature of the data and the availability of resources, this study followed a cumulative validation process, in which the cross-reference method was combined between the available literature and findings. The reliability of the study was guaranteed by keeping records of the face-toface interviews of the research informants. This guide was piloted in a local government agency, then modified as needed before being used for research.

Study setting: The research was conducted in the rural area of Enrekang Regency, South Sulawesi Province, Indonesia. Enrekang District is the highest stunting area in South Sulawesi province with around $43.7 \%$ in $2019^{15}$ and is in the category of 100 priority districts/cities for stunting in Indonesia. ${ }^{16}$

Informants and inclusion criteria: The research informants were selected based on the purposive sampling technique. The criteria for informants in the study were people or officials within the scope of the Enrekang District government who had the authority and were directly involved in making policies related to the handling of stunting problems, and those who were directly involved in implementing stunting handling activities. A total of 13 informants were selected, namely 3 key informants, 2 expert informants, and 8 other informants $(n=13)$.

Sampling, data collection, and processing: Informants were selected using a purposive sampling method, based on presumptions about the required sample characteristics. Each interview lasts 30 to 45 minutes. Research questions were raised and informants were given the freedom to express additional views and comments. All interviews were audio-recorded and the principal investigator took additional field notes. The accuracy and consistency of the interviews were verified by listening to the recordings. The first author analyzes the transcript line by line, which is read repeatedly and then analyzed thematically for its content. Research coauthors verified the themes and content that emerged.

\section{Results}

The political commitment of the Regional Government of Enrekang District to handling the stunting program before and after Covid-19, based on the results of this study includes three dimensions, namely institutional commitment (policies and programs), 
budget commitment, and operational/implementation commitment, as described below.

\section{Institutional Commitment:}

a. Conditions before COVID-19: Stunting activities have been adopted into the Regional Medium Term Development Plan (RMTDP) according to the vision and mission of the elected regents and deputy regents for the 2018-2023 period, as recognized by the following key informants:

“... from the vision and mission of the elected Regent and Deputy, it has been adopted into the RMTDP where the issue of stunting is a priority for Enrekang Regency ... because it has become an indicator in the RMTDP ... starting in 2018 ... because the issue of stunting at that time has become a national issue", Deputy Regent of Enrekang) - KI-1

In addition to specific stunting activities, stuntingrelated activities have also been adopted into regional development planning documents, this is because stunting reduction is a cross-sectoral activity, as explained by the following informants:

“... ..Stunting activities have been adopted into the 5-year development planning document... in the form of cross-sectoral activities... stunting prevention has become a priority in Enrekang Regency. ... ") $(R H, 34$ Years, Chairman of Commission III DPRD Enrekang) - KI-2

“... stunting issues are the main performance indicator for Enrekang District ... stunting is also a national program ... and Enrekang is designated as a stunting locus ..." (RD, 48 years old, Secretary of Regional Development Agency) - KI-3

Stunting activities and indicators have also been adopted into the Strategic Plan, including the Health Office and the Food Security Service, as shown in the following interview:

“... in the Health Office strategic plan there are already special activities for stunting ... "... in the form of maternal and child health, malnutrition, immunization, exclusive breastfeeding, health promotion, clean water and sanitation ... "(ST, 53 Years, Head of Health Service) - KI-4

“... in the 2018-2023 official strategic plan, food security has adopted activities that support the acceleration of stunting reduction ... as a performance indicator of the prevalence of food consumption sufficiency and the proportion of the population with a minimum calorie intake below 1,400 kcal/capita/day ... “, (SY, 55 Years, Head of Food Security Service) - KI-5

Enforcement of Large-Scale Social Restrictions (LSSR) such as school and work vacations; restrictions on activities in public places or facilities; restrictions on transportation modes, ${ }^{5}$ have an impact on handling stunting during the COVID-19 pandemic due to selfisolation, and social distancing. This has resulted in inadequate health services. For example, the Integrated Service Post and Community Health Center services, as explained by the following expert informant (EI).

“... considering that Posyandu is no longer operating and health workers at the Puskesmas are not spared the impact of COVID-19. This situation causes the monitoring of children's development and development activities to stop early in life". (EI-1; EI-2)

Economically, PSBB has an impact on job losses and reduced income, which causes a decrease in people's purchasing power for nutritious food, and increases in poverty. Review the following expert informants.

"On the production side, transportation, storage and sale of food are also disrupted. As a result, nutrition problems in vulnerable groups such as pregnant women and toddlers will increase along with the difficulty of their access to nutritious food. "(EI-2)

"Pregnant women and children under five will experience problems in health and nutrition services, which are essentially stopped by limited access due to the focus of services for Covid-19" (EI-3)

2. Budget Commitment: Refocusing (reallocation and cutting) of the budget of the Enrekang District Government can affect stunting management activities, especially during the COVID-19 pandemic.

a. Reallocation of specific activities for stunting due to Covid-19: Based on the Regulation of the Regent of Enrekang Number 26 of 2020 concerning the Elaboration of Amendments to the District Regional Revenue and Expenditure Budget (RREB). In 2020, data on changes to the budget for special stunting activities are obtained in 4 Regional Apparatus Organizations (RAO) as seen in Table 1, 
Table 1. Reallocation of Specific Activities Budget for Stunting due to COVID-19

\begin{tabular}{|l|l|c|c|c|}
\hline Institutions & Name of Activities & Basic budget (IDR) & After change (IDR) & Difference (IDR) \\
\hline Public Health Office & $\begin{array}{l}\text { Specific nutritional interventions for } \\
\text { stunting management }\end{array}$ & $70,000,000$ & $20,425,000$ & $49,575,000$ \\
\hline $\begin{array}{l}\text { Regional Planning } \\
\text { Agency }\end{array}$ & $\begin{array}{l}\text { Coordination of Stunting Regional } \\
\text { Action Plan (RAD) }\end{array}$ & $145,600,000$ & $117,236,750$ & $28,363,250$ \\
\hline Social services & $\begin{array}{l}\text { Monitoring Providing assistance to } \\
\text { fulfill stunting nutrition }\end{array}$ & $30,000,000$ & 0 & $30,000,000$ \\
\hline $\begin{array}{l}\text { Office of population } \\
\text { control and family } \\
\text { planning }\end{array}$ & $\begin{array}{l}\text { Socialization of stunting prevention in } \\
\text { children in the first 1000 days of life }\end{array}$ & $30,000,000$ & $6,249,000$ & $23,751,000$ \\
\hline Total & & $\mathbf{2 7 5 , 6 0 0 , 0 0 0}$ & $\mathbf{1 4 3 , 9 1 0 , 7 5 0}$ & $\mathbf{1 3 1 , 6 8 9 , 2 5 0}$ \\
\hline
\end{tabular}

"There was a reduction in the budget related to specific stunting activities by an average of $47.8 \%$ spread across 4 RAOs. The budget for special stunting activities in the 2020 Regional Revenue and Expenditure Budget (RREB) main budget is IDR. 275,6 billion, reduced by IDR 131,7 billion so that the remaining budget is IDR 143,9 billion. (NM, 41Th, Head of Regional Financial Management Agency) - I-3 b. Reallocation of the budget for stunting support activities: Refocusing (reallocation and reduction) of stunting support activity budgets sourced from the Special Allocation Fund (Health Operational Costs), is presented in Table 2.

Table 2. Budget reallocation for Stunting support activities (before and during COVID-19)

\begin{tabular}{|c|c|c|c|c|}
\hline \multirow{2}{*}{ No. } & \multirow{2}{*}{ Institutions } & Basic Budget (IDR) & After the change (IDR) & Difference (IDR) \\
\hline & & The years 2020 & The years 2020 & The years 2020 \\
\hline \multicolumn{5}{|c|}{ Public Health Office } \\
\hline \multirow[t]{2}{*}{1} & $\begin{array}{l}9 \text { activities with reduced budget such as maternal } \\
\text { and child health services, the development of } \\
\text { promotional media and information on healthy } \\
\text { living awareness }\end{array}$ & $18,628,854,364$ & $18,305.346 .346$ & $(-323.508,000)$ \\
\hline & $\begin{array}{l}5 \text { fixed budget activities, such as National } \\
\text { Health Insurance (NHI), procurement of medical } \\
\text { equipment. }\end{array}$ & $17,466,738,990$ & $17,466,738,990$ & 0 \\
\hline \multicolumn{5}{|c|}{ Food security service } \\
\hline \multirow[b]{2}{*}{2} & Implementation of nutrition and food precautions & $23,000,000$ & $11,500,000$ & $(-11,500,000)$ \\
\hline & $\begin{array}{l}\text { Utilization yards through the development of the } \\
\text { best-selling food house area (BSFHA) }\end{array}$ & $64,860,000$ & $41,368,350$ & $(-23,491,650)$ \\
\hline \multicolumn{5}{|c|}{ Social Services } \\
\hline 3 & $\begin{array}{l}\text { Coordination of mentoring, and empowerment } \\
\text { monitoring of the Family Hope Program (FHP) }\end{array}$ & $170,300,000$ & $73,050,000$ & $(-97,250,000)$ \\
\hline \multicolumn{5}{|c|}{ Housing office for residential areas and spatial planning } \\
\hline 4 & Community Sanitation (latrine procurement) & $2,337,500,000$ & $3,177,828,000$ & $840,328,000$ \\
\hline
\end{tabular}

There were 18 supporting activities for stunting, 12 activities experienced a reduction in funds, 5 activities did not change the budget, the remaining 1 activity actually increased the budget, namely the provision of latrines, as explained by the following informant. 
“... out of 18 activities supporting stunting, 12 of them experienced a budget decline of IDR 457billion (2.4\%). There are 5 activities whose budgets are fixed.

There is 1 activity that has experienced a significant increase in the budget, namely the community sanitation program (provision of latrines) at the Housing, Settlement and Spatial Planning Agency from IDR 2.3 trillions to Rp. 3.2 trillions, an increase of IDR 840 thousand (35.9\%). (NM, 41 Years, Head of BPKAD) $K I-6)$

\section{c. Operational}

Commitment/Activity

Implementation: Stunting policies and programs (before and after COVID-19) can be seen in Annex 1 Table 3. Based on the results of in-depth interviews with several informants, it was stated that the COVID-19 pandemic required adjustment of activities based on health protocols in the form of physical distancing.

“....Several cross-sectoral activities, such as stunting deliberations, coaching and mentoring, including monitoring in the locus village, were still implemented but limited the number of participants. Even the training of stunting holders in the district was abolished due to budget reduction "'(I-10; --------)

Planning before and after COVID-19 took place, several stunting management program activities did not change but participants were limited according to health protocols. In addition, there was a reduction in incentives for Community Empowerment Cadres (CEC) as a result of refocusing the APBD so that it was estimated that they could reduce their performance. Training for stunting program holders at the district and health center levels was apparently omitted.

\section{Discussion}

The political commitment of the local government of Enrekang District in handling stunting can be discussed in three dimensions including institutional commitment, budget commitment, and operational/ implementation commitment of stunting before and during the COVID-19 pandemic.

Institutional Commitment: Institutional commitment is a rhetorical commitment converted into a substantive policy infrastructure including institutions responsible for coordinating action, adoption of enabling legislation, policies and policy instruments commensurate with the severity of the problem and the commitment of mid-level bureaucrats who are responsible for coordinating action. ${ }^{11}$

The COVID-19 pandemic that has hit the world including Indonesia has had an impact on the handling of stunting in high-risk areas such as EnrekangDistrict where the stunting rate reached $47.5 \%$ in $2019 .{ }^{15}$

The enactment of Large-Scale Social Restrictions (LSSR) which close schools and workplaces, restrictions on social activities and public facilities, restrictions on transportation modes, and even the movement of people from one city to another. This has an impact on decreasing family income, disruption of food stocks, barriers to access to health services. ${ }^{17-18}$ Increases the risk of all forms of malnutrition, even maternal and child mortality. ${ }^{19}$ Without adequate intervention, it will interfere with early life nutrition and have the potential to disrupt children's growth and development and have a lifetime impact on the formation of basic human capital. ${ }^{20}$ Reduced political commitment has been identified as the main reason for the low priority received by government food and nutrition interventions relative to the high disease burden caused by malnutrition. ${ }^{11}$

The Village Ministry has taken steps to break the chain of spreading the Coronavirus into the village by holding the Village Cash Workforce Program (VCWP). Workers who are involved in the program will not place too much emphasis on workers' abilities or skills.

The VCWP program will target workers who come from poor, unemployed, and underemployed families, as well as other members of marginalized communities.

Then, wages for workers will be given daily and in implementing VCWP, they must prioritize health protocols such as physical distancing and others.

Many programs have expanded their targets since the COVID-19 crisis hit. The Sembako Program that was given to 15.2 million people has now received 20 million recipients. The value also increased, from 150 thousand rupiahs to 200 thousand rupiahs.

Besides, the Family Hope Program (FHP), Direct Cash Assistance (DCAT), Pre-Employment Cards, discounted electricity rates, and credit payment relief for the informal sector was launched. The same is done in Ethiopia for food insecurity in the form of the Productive Safety Net Program aimed at providing emergency food assistance to 15 million people who are vulnerable to 
food insecurity and are considered important for the narrative of reducing stunting in the country. ${ }^{21}$

Meanwhile, the Unconditional Cash Transfer (UCT) amount was around \$ 42 USD per month for 3 months per beneficiary family. The same was done in Peru $^{22}$ and the Kyrgyz Republic ${ }^{23}$, using a successful financial incentive-based model as a means of providing a social safety net to reach marginalized and vulnerable populations.

Budget Commitment: The budget commitment in dealing with nutrition problems is public expenditure, for example the percentage of the government budget that is spent on nutrition/food issues. ${ }^{10}$ Budgetary commitment is an allocation of resources allocated to a specific problem relative to a certain benchmark. ${ }^{11}$

The impact of COVID-19 has forced the Indonesian government to refocus the health budget, including priority programs for handling stunting in the regions to prevent the spread of COVID-19. The results of this study indicate that the budget refocusing for specific stunting activities in Enrekang District (Appendix 1 Table-1) has an average reduction of $47.8 \%$. Likewise, the budget for stunting support activities in Enrekang District (Attachment 1: Table 2) was reduced by $2.4 \%$. for 12 types of activities from 18 activities. In addition, there are 5 activities that do not change the budget which is more tangible as a Special Allocation Fund (SAF) such as the National Health Insurance (NHI), purchasing medical equipment, childbirth insurance, and community-based total sanitation.

But interestingly, from refocusing the stunting support budget, there was a drastic increase in the community sanitation program for latrine provision by $35.9 \%$ from IDR 2.3 trillion (US \$ 161,207) to IDR 3.2 trillion (US \$219,161). This illustration shows that refocusing the stunting support budget in Enrekang District is a reallocation of the focus of the community sanitation program for the provision of latrines. Based on the results of in-depth interviews, it was revealed that sanitation is one of the main triggers that contribute to increased stunting.

Yet according to Shekar M, et al. related to the increase in the annual cost scale for the period 20162025 which was carried out in 37 countries with a high prevalence of stunting, including Indonesia. The research focuses on a package of specific nutritional interventions that have been shown to be effective. The results of the study indicate that the 10-year budget needed to increase specific nutrition interventions is 49.5 billion dollars, to achieve this target current funding must increase from 2.6 billion to 7.4 billion on average per year. Reaching stunting targets is feasible but will require a large and coordinated investment in a supportive environment. ${ }^{24}$

\section{Operational/implementation}

commitment:

The results of the study revealed that monitoring of nutritional status by Community Empowerment Cadres (CEC) in villages affected by Covid-19 was due to a reduction in the regional government budget, in which the incentives for CEC, especially in remote and difficult to reach villages such as Enrekang District, the role of CEC is very effective in the community health education system as carried out by Ethiopian health extension officers (HEWs) ${ }^{21}$ exhibit models that are successful in mobilizing community health workers (CHWs; who receive basic and commodity training) to deliver vaccines, nutritional supplements, health and nutrition education, and even reproductive, maternal and newborn care.

What is interesting about the reallocation of the budget for stunting support activities (Appendix 1: Table 2) shows that the Enrekang Regional Government's attention to the provision of latrines to meet adequate sanitation and hygiene is very important for the agenda for overcoming COVID-19 and other positive health impacts. Beal $\mathrm{T}$ et.al, reviewing the determinants of stunting in children in Indonesia, revealed that children from households with poor latrines and untreated drinking water were at higher risk of stunting. ${ }^{26} \mathrm{The}$ commitment of the district government of Enrekang is in line with experiences in several other countries in creating a healthy environment by reducing open defecation and encouraging hygienic practices and has been linked to reducing stunting in Senegal ${ }^{25}$ and Ethiopia $^{21}$ focusing on change. the behavior to create a village free of open defecation. These programs spark community desire for collective change by encouraging innovation and context-specific solutions while fostering a sense of community ownership. Community-Led Total Sanitation (CLTS) programs in sample countries such as Nepal have had an important impact on reducing stunting in childhood.

Reducing the budget for the development of promotional media and health education during the COVID-19 pandemic in Enrekang District, when schools and workplaces are closed, can hinder the 
Community's Clean and Healthy Behavior (CCHB) program, and reduce stunting, and prevent the spread of COVID-19. It is better to involve women's groups and other health communities to communicate the best health practices in rural communities. Several countries, for example in reducing stunting, have demonstrated the potential use and impact of this mechanism on stunting reduction. Learning from their experience with Ebola, the CHW Senegal program ${ }^{25}$ has proven to be an effective mechanism for communicating health best practices to the public. The FCHV program in Nepal ${ }^{27}$ and the HEW in Ethiopia ${ }^{21}$ also have a very successful component of health and nutrition counseling. The Republic of Kyrgyzstan uses women's support groups in the community as a means of keeping up-to-date with the health situation and sharing knowledge ${ }^{23}$, and adaptable model for accelerating stunting reduction. including prevention of the spread of COVID-19. It is better to involve women's groups and other health communities to communicate the best health practices in rural communities. Several countries, for example in reducing stunting, have demonstrated the potential use and impact of this mechanism on stunting reduction. Learning from their experience with Ebola, the CHW Senegal program ${ }^{25}$ has proven to be an effective mechanism for communicating health best practices to the public. The FCHV program in $\mathrm{Nepal}^{26}$ and the HEW in Ethiopia ${ }^{21}$ also have highly successful health and nutrition counseling components. The Republic of Kyrgyzstan uses women's support groups in the community as a means of keeping up-to-date with the health situation and sharing knowledge ${ }^{23}$, and adaptable model for accelerating stunting reduction.

The results of in-depth interviews with experts and UNICEF estimates show that in the absence of timely action, the number of children who experience wasting or acute malnutrition under 5 years of age could increase globally by around 15 percent this year due to COVID-19. ${ }^{3}$ It is in this context that political commitment Regional and central governments need to rearrange strategies and priorities in handling stunting during the COVID-19 pandemic based on data.

\section{Conclusion}

The COVID-19 pandemic has an impact on the political commitment to handling stunting due to the enactment of Large Scale Social Restriction (LSSR) and budget refocusing. The low political commitment of the Local Government of Enrekang Regency can be seen from the reduction of incentives for monitoring the nutritional status of Community Empowerment Cadres (CEC), and reducing the budget for developing media for promotion and health education, which have an impact on the weak performance of cadres and health workers. In a situation of COVID-19 village cadres can do double duty to reduce the spread of COVID-19.

On the other hand, the reallocation of the accumulated stunting support budget on the provision of latrines shows a high political commitment to fulfill sanitation and hygiene to support stunting reduction.

Acknowledgment : We highly say thank you to the local government of Enrekang Regency who have given a permission to conduct this research.

Ethical Clearance: Taken from Hasanuddin University ethical committee.

Source of Funding: LP2M Hasanuddin University

\section{Conflict of Interest: Nil}

\section{References}

1. Stunting : What is and What it means, Concern wordwise US, July 21, 2019 [cited : Oct. 1, 2020). Available from:https://www.concernusa.org/story/ what-is-stunting/

2. Global Nutrition Report. Global Nutrition Report 2020. [citedOct. 1, 2020] [Internet]. Available from: https://globalnutritionreport.org/reports/2020global-nutrition-report/

3. UNICEF Indonesia. Number of malnourished children could increase sharply due to COVID-19 unless swift action is taken https://www.unicef.org/ indonesia/press-releases/number-of-malnourishedchildren-in-indonesia-could-increase-sharply-dueto-covid-19. 2020.

4. Fox, Ashley M. et.al. Measuring political commitment and opportunities to advance food and nutrition security : pilotinga rapid assessment tool, Health Policy and Planning 2015: Jun 30(5): 566-578. Available from : https://doi.org/10.1093/ heapol/czu035

5. Ministry of Health of the Republic of Indonesia, Regulation of The Minister of Health of Republic Indonesia Number 9 of 2020 about Guidelines for Scale of Social Restrictions on Accelerating the Handling of Corona Virus Disease 2019 (COVID-19), Jakarta, Ministry of Health. 
6. Kluge HHP, Wickramasinghe $\mathrm{K}$, Rippin HL, Mendes R, Peters DH, Kontsevaya A, Breda J. Comment: prevention and control of noncommunicable diseases in the COVID-19 response. Lancet. [Internet] 2020;6736(20):2019-21. Available from: http://dx.doi.org/10.1016/S01406736(20)31067-9

7. UNICEF. Don't let children be the hidden victims of COVID-19 pandemic: statement by UNICEF Executive Director Henrietta Fore [Internet]. UNICEF;. 2020; [cited July 26, 2020]. Available from: https://www.unicef.org/press-releases/dontlet-children-be-hidden-victims-covid-19-pandemic

8. Nadia Akseer, Goutham Kandru, Emily C. Keats, and ZulfiqarA.Butta, COVID-19 pandemic and mitigation strategies : implications for maternal and child health and nutrition; The American Journal of Clinical Nutrition 2020;00:1-6. Downloaded from https://doi.org/10.1093/ajen/nqaa171

9. Creswell, J. W.. Research Design: Qualitative, Quantitative and Mixed Method Approaches 2014; (4th ed.). Thousand Oaks, CA: Sage

10. TeLintelo, DolfJ.H, et.al. The Hunger And Nutrition Commitment Index (HANCI 2012) Measuring the Political Commitment to Reduce Hunger and Undernutrition in Developing Countries. Institute of Development Studies UK. 2013.

11. Fox, Ashley M. et.al. Measuring Political Commitment for Food AND Nutrition Security. UNICEF Nutrition Working Paper, New York: UNICEF and MDG Fund. 2013

12. Baker, Phillip, et.al..What drives political commitment for nutrition? A review and framework synthesis to inform the United Nations Decade of Action on Nutrition. BMJ Global Health. 2018; 1-14. Downloaded form http://dx.doi.org/10.1136/ bmjgh-2017-000485

13. Secretariat of the Vice President of the Republic of Indonesia. TNP2K. National Strategy for Accelerated Stunting Prevention 2018-2024 http:// www.tnp2k.go.id/filemanager/files/Rakornis\% 202018/Session\% 201_01_RakorStuntingTNP2K_ Stranas_22Nov2018.pdf

14. DeJonckheere M, Vaughn LM .Semistructured interviewing in primary care research: a balance of relationship and rigour, Fam Med Com Health 2019; 7:e000057. Available from http://dx.doi. org/10.1136/fmch-2018-000057. 2019.
15. Ministry of Health of the Republic of Indonesia. National Report, Basic Health Research 2018, Agency for Health Research and Development, Jakarta: Ministry of Health. 2019.

16. National Team for Accelerating Poverty Reduction (NTAPR), Secretariat of the Vice President of the Republic of Indonesia: 100 Priority Districts/ Cities for Stunting (Stunting) Intervention, Jakarta. NTAPR \& Secretariat of the Vice President of the Republic of Indonesia. 2017.

17. The World Bank. Food security and COVID-19. [Internet]. The World Bank; [cited July 26, 2020]. Available from: https://www.worldbank.org/en/ topic/agriculture/brief/food-security-and-covid-19. 2020.

18. Secretariat of the Vice President of the Republic of Indonesia, National Team for Accelerating Poverty Reduction (NTAPR). National Strategy for Accelerated Stunting Prevention 2018-2024 http:// www.tnp2k. go.id/filemanager/files/Rakornis\%20 2018/Session\%201_01_RakorStuntingTNP2K_ Stranas_22Nov2018.pdf

19. Rachel Toku-Appriah, COVID-19 Pandemic Could Cause Widespread Stunting in Ghana, Global Citizen, Available from: https://www.globalcitizen. org/en/issue/food-hunger/. 2020

20. Martorell, Reynaldo. "Improved nutrition in the first 1000 days and adult human capital and health." American journal of human biology : the official journal of the Human Biology Council vol. 29,2 (2017): 10.1002/ajhb.22952. available from: https://doi.org/10.1002/ajhb.22952

21. Tasic H, Akseer N, Gebreyesus SH, Ataullahjan A, Brar S, Confreda E, Conway K, Endris BS, Islam $\mathrm{M}$, Keats $\mathrm{E}$ et al. Drivers of stunting reduction in Ethiopia: a country case study. Am J ClinNutr. 2020. Downloaded from: https://doi:10.1093/ajcn/ nqaa163

22. Huicho L, Vidal-Cárdenas E, Akseer N, Brar S, Conway K, Islam M, Juarez E, Rappaport A, Tasic $\mathrm{H}$, Vaivada $\mathrm{T}$ et al. Drivers of stunting reduction in Peru: a country case study. Am J Clin Nutr. 2020. Donwloaded from https://doi.org/10.1093/ajcn/ nqaa164

23. Wigle JM, Akseer N, Mogilevskii R, Brar S, Conway K, Enikeeva Z, Iamshchikova M, Islam M, Kirbasheva D, Rappaport A et al. Drivers of stunting reduction in Kyrgyz Republic: a country case study. 
Am J ClinNutr. 2020. Downloaded foromhttps:// academic.oup.com/ajcn/article/112/2/251/5860091

24. Shekar M, Kakietek J, D'Alimonte MR, Rogers HE, Eberwein JD, Akuoku JK, Pereira A, SoeLin S, Hecht R. Reaching the global target to reduce stunting: an investment framework, Health Policy Plan. 2017 Jun 1;32(5):657-668. https://doi. org/10.1093/heapol/czw184

25. Brar S, Akseer N, Sall M, Conway K, Diouf I, Everett K, Islam M, Sène PIS, Tasic H, Wigle J et al. Drivers of stunting reduction in Senegal: a country case study. Am J ClinNutr. 2020. Available from: https://doi:10.1093/ajen/nqaa151.
26. Beal T, Tumilowicz A, Sutrisna A, Izwardy D, Neufeld LM. A review of child stunting determinants in Indonesia. Matern Child Nutr. 2018;14(4):e12617. Available form : https://doi. org/10.1111/mcn.12617

27. Conway K, Akseer N, Subedi RK, Brar S, Bhattarai B, Dhungana RR, Islam M, Mainali A, Pradhan $\mathrm{N}$, Tasic $\mathrm{N}$ et al. Drivers of stunting reduction in Nepal: a country case study. Am J ClinNutr. 2020. Downloaded from https://doi.org/10.1093/ajcn/ nqaa218 